\title{
Allorhizobium undicola gen. nov., sp. nov., nitrogen-fixing bacteria that efficiently nodulate Neptunia natans in Senegal
}

\author{
Philippe de Lajudie, ${ }^{1,2}$ Etike Laurent-Fulele, ${ }^{1}$ Anne Willems, ${ }^{2,3}$ \\ Urbain Torck, ${ }^{2}$ Renata Coopman, ${ }^{2}$ Matthew D. Collins, ${ }^{3}$ Karel Kersters, ${ }^{2}$ \\ Bernard Dreyfus ${ }^{1} \dagger$ and Monique Gillis ${ }^{2}$
}

\author{
Author for correspondence: Monique Gillis. Tel: +329264 5117. Fax: +329264 5092/5346. \\ e-mail: Moniek.Gillis@rug.ac.be
}

\footnotetext{
1 Laboratoire de Microbiologie des Sols, ORSTOM BP 1386, Dakar, Senegal, West Africa

2 Laboratorium voor Microbiologie, Universiteit Gent, K.-L.

Ledeganckstraat, 35, B9000 Ghent, Belgium

${ }^{3}$ Microbiology Department, Reading Laboratory, Institute of Food Research, Earley Gate, Whiteknights Road, Reading RG6 6BZ, UK
}

\begin{abstract}
A group of nodule isolates from Neptunia natans, an indigenous stemnodulated tropical legume found in waterlogged areas of Senegal, was studied. Polyphasic taxonomy was performed, including SDS-PAGE of total proteins, auxanography using API galleries, host-plant specificity, PCR-RFLP of the internal transcribed spacer region between the 165 and the 235 rRNA coding genes, 165 rRNA gene sequencing and DNA-DNA hybridization. It was demonstrated that this group is phenotypically and phylogenetically separate from the known species of Rhizobium, Sinorhizobium, Mesorhizobium, Agrobacterium, Bradyrhizobium and Azorhizobium. Its closest phylogenetic neighbour, as deduced by $16 \mathrm{~S}$ rRNA gene sequencing, is Agrobacterium vitis (96.2\% sequence homology). The name Allorhizobium undicola gen. nov., sp. nov., is proposed for this group of bacteria, which are capable of efficient nitrogen-fixing symbiosis with Neptunia natans, and the type strain is ORS 992 ${ }^{\top}$ ( = LMG 11875').
\end{abstract}

Keywords: Allorhizobium undicola, Neptunia natans, tropical rhizobia, polyphasic taxonomy, nitrogen fixation

\section{INTRODUCTION}

Neptunia natans L.f. (Druce), previously Neptunia oleracea Lour., McVaugh 1987 (Subba Rao et al., 1995), is an annual aquatic legume that is indigenous to waterlogged areas of Senegal. N. natans produces floating stems and roots containing white, spongy, internodal tissue and nodes with bright-red nodules and adventitious roots (Allen \& Allen, 1981; Schaede, 1940). The mode of root infection of N. natans (Subba Rao et al., 1995) is similar in many respects to that of other tropical legumes, such as Aeschynomene americana (Napoli et al., 1975), Neptunia plena (James et al., 1992) and Sesbania rostrata (Ndoye et al., 1994).

\footnotetext{
† Present address: LSTM ORSTOM/CIRAD-Forêt, Baillarguet, BP 5035, 34032 Montpellier Cedex 1, France.

Abbreviations: ITS, internal transcribed spacer; YMA, yeast mannitol agar; YEB, yeast extract peptone medium; TY, tryptone yeast extract medium.

The EMBL accession number for the 165 rRNA gene sequence of strain LMG 11875 reported in this paper is $\mathrm{Y} 17047$.
}

Bacteria enter natural wounds caused by splitting of the epidermis and emergence of young lateral roots. Bacteria spread first intercellularly, then through intercellular infection threads towards the meristematic cells of the nodule (Schaede, 1940). The vascular bundles of the nodules are connected to the vasculature of the adventitious roots and not to that of the stem, indicating that they are root nodules rather than true stem nodules (Schaede, 1940; James et al., 1992; Subba Rao et al., 1995). N. natans is being evaluated as green manure for rice cultivation in India and is consumed in South-East Asia (Subba Rao et al., 1995). N. natans nodule bacterial isolates have been reported to induce small, white ineffective nodules on Medicago sativa and Ornithopus spp. (Subba Rao et al., 1995) but not on roots of Cicer arietinum, Lupinus albus, Lupinus angustifolius, Vicia faba, Trifolium subterraneum, Glycine max and Macroptilium atropurpureum. N. natans was recently reported to be nodulated by Mesorhizobium plurifarium strains isolated from Acacia (de Lajudie et al., 1998). N. natans nodule isolates have been reported to be fast growers (Dreyfus et al., 1984) but have not yet been taxonomically characterized. 
Phylogenetically, rhizobia belong in the alpha-2 subclass of the Proteobacteria (Stackebrandt et al., 1988; Sawada et al., 1993; Willems \& Collins, 1993; Yanagi \& Yamasato, 1993; Young, 1991), and several genera have been recognized, i.e. Rhizobium, Bradyrhizobium, Azorhizobium, Sinorhizobium and Mesorhizobium (for a review see Young \& Haukka, 1996). Polyphasic taxonomy has revealed that members of the genus Rhizobium are phylogenetically intertwined with members of the genus Agrobacterium, to which they are more closely related than to Azorhizobium and Bradyrhizobium (Sawada et al., 1993; Willems \& Collins, 1993; Yanagi \& Yamasato, 1993). In Agrobacterium, the original species (Agrobacterium tumefaciens, Agrobacterium radiobacter and Agrobacterium rhizogenes) were created on the basis of their phytopathogenic properties, which are mainly governed by plasmidborne genes and do not correlate with the taxa found by polyphasic taxonomy (Kersters \& De Ley, 1984). For nomenclatural reasons, Agrobacterium tumefaciens must be retained as the type species of Agrobacterium. Consequently, no definite renaming of the species was proposed by Kersters \& De Ley (1984), although a temporary division into four groups was suggested, reflecting the polyphasic results. Agrobacterium bv. 1 (containing the type strains of Agrobacterium tumefaciens and Agrobacterium radiobacter) constitutes the first group, Agrobacterium bv. 2 including the type strain of Agrobacterium rhizogenes constitutes a second group and a third taxon corresponds to the species Agrobacterium vitis; Agrobacterium rubi was considered to have a separate position and represents the fourth group. Later, comparison of the sequences of the 16S rRNA genes (Sawada et al., 1993; Willems \& Collins, 1993; Yanagi \& Yamasato, 1993) revealed four phylogenetic sublineages on the Agrobacterium-Rhizobium branch: (i) a first sublineage contains Agrobacterium bv. 1, Agrobacterium rubi and Agrobacterium vitis; Rhizobium galegae and the recently proposed new species Rhizobium giardinii (Amarger et al., 1997) also belong to this sublineage but have somewhat separate positions; (ii) a second phylogenetic sublineage contains Rhizobium leguminosarum (type species of Rhizobium), Rhizobium tropici, Rhizobium etli, Agrobacterium bv. 2 and a recently proposed new species, Rhizobium gallicum (Amarger et al., 1997); (iii) a third sublineage was considered sufficiently different to deserve a separate genus status, for which the name Sinorhizobium had priority. Sinorhizobium contains Sinorhizobium meliloti, Sinorhizobium fredii, Sinorhizobium xinjiangense, Sinorhizobium terangae, Sinorhizobium saheli (de Lajudie et al., 1994; Trüper \& de' Clari, 1997) and Sinorhizobium medicae (Rome et al., 1996); (iv) the fourth sublineage consists of species recently transferred in the new genus Mesorhizobium (Jarvis et al., 1997), namely Mesorhizobium loti, Mesorhizobium huakuii, Mesorhizobium ciceri, Mesorhizobium tianshanense, Mesorhizobium mediterraneum (Jarvis et al., 1997) and Mesorhizobium plurifarium (de Lajudie et al., 1998).
Following the proposition of Sawada et al. (1993) to name Agrobacterium bv. 1 strains and Agrobacterium bv. 2 strains Agrobacterium radiobacter and Agrobacterium rhizogenes respectively, Bouzar (1994) requested a Judicial Opinion to decide whether Agrobacterium radiobacter or Agrobacterium tumefaciens should be the type species of Agrobacterium. Because this decision is still pending, we use here the nomenclature proposed by Kersters \& De Ley (1984). Here we study a new group of fast-growing rhizobia isolated from $N$. natans nodules collected in Dakar and in the Sine Saloum region of Senegal, where this plant grows naturally. We performed whole-cell protein analysis by SDS-PAGE, PCR-RFLP of the internal transcribed spacer (ITS) region between $16 \mathrm{~S}$ and $23 \mathrm{~S}$ rRNA genes, 16S rRNA gene sequencing, DNA-DNA hybridizations, and auxanographic tests using API 50 galleries. Based on the findings of this polyphasic study, we conclude that this group of rhizobia belongs to the Agrobacterium rRNA sublineage, with Agrobacterium vitis as its closest phylogenetic neighbour, and deserves a separate genus and species status, for which the name Allorhizobium undicola, gen. nov., sp. nov., is proposed.

\section{METHODS}

Bacterial strains. Rhizobium strains were isolated as previously described (de Lajudie et al., 1994) from naturally occurring nodules on adventitious roots of $N$. natans. All strains used are listed in Table 1. They were checked for purity by repeated streaking and by microscopical examination. The identity of the nodulating strains was verified by plant infection tests on the original host plants. We included type or representative strains of the different Rhizobium, Bradyrhizobium, Azorhizobium, Mesorhizobium, Sinorhizobium and Agrobacterium species. Mycoplana, Ochrobactrum and Phyllobacterium representatives were included in the auxanographic tests.

Growth and culture conditions. All Rhizobium and Bradyrhizobium strains were maintained on yeast mannitol agar (YMA), containing $\left(\mathrm{g} \mathrm{l}^{-1}\right)$ : mannitol, 10 ; sodium glutamate, $0.5 ; \mathrm{K}_{2} \mathrm{HPO}_{4}, 0.5 ; \mathrm{MgSO}_{4} .7 \mathrm{H}_{2} \mathrm{O}, 0.2 ; \mathrm{NaCl}, 0.05 ; \mathrm{CaCl}_{2}$, $0.04 ; \mathrm{FeCl}_{3}, 0.004$; yeast extract (Difco), 1 ; agar, $20 ; \mathrm{pH} 6.8$. Azorhizobium and Agrobacterium strains were maintained on yeast extract peptone medium (YEB) containing in $\mathrm{g}^{-1}$

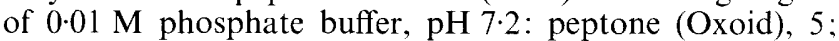
yeast extract (Oxoid), 1; beef extract (Oxoid), 5 ; sucrose, 5 and $\mathrm{MgSO}_{4} \cdot 7 \mathrm{H}_{2} \mathrm{O}, 0.592$. All strains were stored at $-80^{\circ} \mathrm{C}$ on the same medium plus $15 \%(\mathrm{v} / \mathrm{v})$ glycerol. For protein and DNA preparations we used tryptone yeast extract medium (TY) containing ( $\mathrm{g}^{-1}, \mathrm{pH} \mathrm{6.8-7)}$ : tryptone (Oxoid), 5 ; yeast extract (Oxoid), $0.75 ; \mathrm{KH}_{2} \mathrm{PO}_{4}, 0.454 ; \mathrm{Na}_{2} \mathrm{HPO}_{4}$. $12 \mathrm{H}_{2} \mathrm{O}, 2 \cdot 388 ; \mathrm{CaCl}_{2}, 1$; agar, 20. For protein preparation, TY with LabM agar was used. Mycoplana, Ochrobactrum and Phyllobacterium strains were maintained on nutrient agar containing $\left(\mathrm{g} \mathrm{l}^{-1}\right)$ : beef extract (Oxoid), 1 ; yeast extract (Oxoid), 2; peptone (Oxoid), 5; NaCl, 5; pH 7.4; agar, 20.

Morphological tests. Cell dimensions and morphology were determined on living cells by phase-contrast microscopy.

Plant infection tests. The seeds were scarified and surface sterilized with concentrated sulfuric acid. The duration of treatment (min) in $\mathrm{H}_{2} \mathrm{SO}_{4}$ for the different plant species was 
Table 1. Strains used

ATCC, American Type Culture Collection, Rockville, MD, USA; BR and FL, strains from the CNPBS/EMBRAPA, Centro Nacional de Pesquisa em Biologia do Solo, Seropédica 23851, Rio de Janeiro, Brazil/Emprasa Brasiliera de Pesquisa

Agropequaria; CFN, Centro de Investigacion sobre Fijacion de Nitrogeno, Universidad Nacional Autonoma de México, Cuernavaca, Mexico; CIAT, Rhizobium Collection, Centro International de Agricultura Tropical, Cali, Columbia; HAMBI, Culture Collection of the Department of Microbiology, University of Helsinki, Helsinki, Finland; IAM, Institute for Applied Microbiology, University of Tokyo, Tokyo, Japan; LMG, Collection of Bacteria of the Laboratorium voor Microbiologie, K.-L. Ledeganckstraat, 35, B-9000 Ghent, Belgium; NCPPB, National Collection of Plant-pathogenic bacteria, Harpenden Laboratory, Hertfordshire, UK; NZP, Culture Collection of the Department for Scientific and Industrial Research, Biochemistry Division, Palmerston North, New Zealand; ORS, ORSTOM Collection, Institut Français de Recherche Scientifique pour le Développement en Coopération, BP 1386, Dakar, Senegal; Pan., Panagopoulos, C., Crete, Greece; USDA, US Department of Agriculture, Beltsville, MD, USA; UPM, Universidad Politécnica Madrid, Spain.

\begin{tabular}{|c|c|c|c|c|c|}
\hline Strain* & LMG no. & $\begin{array}{l}\text { Other strain } \\
\text { designation }\end{array}$ & Host plant or origin & Geographical origin & Reference or source \\
\hline \multicolumn{6}{|c|}{ Allorhizobium undicola } \\
\hline ORS 991 & 11874 & & Neptunia natans & $\begin{array}{l}\text { Senegal (North } \\
\text { Kaolack) }\end{array}$ & This work \\
\hline ORS $992^{\mathrm{T}}$ & $11875^{\mathrm{T}}$ & & Neptunia natans & Senegal (Kaolack) & This work \\
\hline ORS 995 & 11876 & & Neptunia natans & $\begin{array}{l}\text { Senegal (South } \\
\text { Kaolack) }\end{array}$ & This work \\
\hline ORS 996 & 11877 & & Neptunia natans & $\begin{array}{l}\text { Senegal (South } \\
\text { Kaolack) }\end{array}$ & This work \\
\hline ORS 997 & 11878 & & Neptunia natans & $\begin{array}{l}\text { Senegal (North } \\
\text { Kaolack) }\end{array}$ & This work \\
\hline ORS 998 & 11879 & & Neptunia natans & $\begin{array}{l}\text { Senegal (Dakar-Bel } \\
\text { Air) }\end{array}$ & This work \\
\hline \multicolumn{6}{|c|}{ Mesorhizobium plurifarium } \\
\hline ORS 1001 & 7836 & & Acacia senegal & Senegal & $\begin{array}{l}\text { de Lajudie et al. } \\
\text { (1998) }\end{array}$ \\
\hline ORS $1014 \mathrm{t} 1$ & $7849 \mathrm{t} 1$ & & Acacia senegal & Senegal & $\begin{array}{l}\text { de Lajudie et al. } \\
\text { (1998) }\end{array}$ \\
\hline ORS 1002 & 7854 & & Acacia senegal & Senegal & $\begin{array}{l}\text { de Lajudie } \text { et al. } \\
\text { (1998) }\end{array}$ \\
\hline ORS 1.3 & 7921 & & Acacia sp. & Senegal & $\begin{array}{l}\text { de Lajudie } \text { et al. } \\
\text { (1998) }\end{array}$ \\
\hline ORS 1018 & 11881 & & Acacia senegal & Senegal & $\begin{array}{l}\text { de Lajudie } \text { et al. } \\
\text { (1998) }\end{array}$ \\
\hline ORS 1037 & 11895 & & Acacia senegal & Senegal & $\begin{array}{l}\text { de Lajudie et al. } \\
\text { (1998) }\end{array}$ \\
\hline ORS 1040 & 11898 & & Acacia senegal & Senegal & de Lajudie et al. \\
\hline HAMBI 1487 & 14925 & & Acacia senegal & Soudan & $\begin{array}{l}\text { de Lajudie et al. } \\
\text { (1998) }\end{array}$ \\
\hline \multicolumn{6}{|c|}{ Mesorhizobium loti } \\
\hline $3 \mathrm{~F} 3 \mathrm{Cl}$ & 4269 & & Wisteria frutescens & & Jarvis et al. (1986) \\
\hline NZP 2230 & 6126 & & Lotus maroccanus & Morocco & Jarvis et al. (1986) \\
\hline $\mathrm{NZP} 2213^{\mathrm{T}}$ & $6125^{\mathrm{T}}$ & ORS $664^{\mathrm{T}}$ & Lotus tenuis & New Zealand & Jarvis et al. (1986) \\
\hline NZP 2037 & 6123 & ORS 652 & Lotus divaricatus & New Zealand & Jarvis et al. (1986) \\
\hline NZP 2014 & 6124 & & Lotus corniculatus & & Jarvis et al. (1986) \\
\hline \multicolumn{6}{|c|}{ Mesorhizobium ciceri } \\
\hline $\mathrm{UPM}-\mathrm{Ca}^{\mathrm{T}}$ & $17150^{\mathrm{T}}$ & ORS $2738^{\mathrm{r}}$ & Cicer arietinum $\mathrm{L}$. & Spain & Nour et al. (1994) \\
\hline 522 & 17149 & & Cicer arietinum $\mathrm{L}$. & Russia & Nour et al. (1994) \\
\hline \multicolumn{6}{|c|}{ Mesorhizobium mediterraneum } \\
\hline $\mathrm{Ca}-36^{\top}$ & $17148^{T}$ & ORS $2739^{T}$ & Cicer arietinum $\mathrm{L}$. & Spain & Nour et al. (1995) \\
\hline UPM-Cal42 & 14990 & & Cicer arietinum $\mathrm{L}$. & Spain & Nour et al. (1995) \\
\hline \multicolumn{6}{|c|}{ Mesorhizobium sp. (Cicer) genospecies 4} \\
\hline IC-60 & 14995 & & Cicer arietinum $\mathrm{L}$. & India & Nour et al. (1995) \\
\hline
\end{tabular}


P. de Lajudie and others

Table 1 (cont.)

\begin{tabular}{|c|c|c|c|c|c|}
\hline Strain* & LMG no. & $\begin{array}{c}\text { Other strain } \\
\text { designation }\end{array}$ & Host plant or origin & Geographical origin & Reference or source \\
\hline \multicolumn{6}{|l|}{ Mesorhizobium huakuii } \\
\hline IAM $14158^{\mathrm{T}}$ & $14107^{1}$ & ORS $1752^{\mathrm{T}}$ & Astragalus sinicus & Nanjing, China & Chen et al. (1991) \\
\hline \multicolumn{6}{|l|}{ Mesorhizobium tianshanense } \\
\hline $\mathrm{A}-1 \mathrm{BS}^{\mathrm{T}}$ & $15767^{\mathrm{T}}$ & ORS $2640^{\mathrm{T}}$ & $\begin{array}{r}\text { Glycyrrhiza } \\
\text { pallidiflora }\end{array}$ & Xinjiang, China & Chen et al. (1995) \\
\hline \multicolumn{6}{|l|}{ Sinorhizobium fredii } \\
\hline USDA $205^{\mathrm{T}}$ & $6217^{\mathrm{T}}$ & ORS $669^{\mathrm{T}}$ & Glycine max & Honan, China & Jarvis et al. (1986) \\
\hline USDA 191 & 8317 & & Soil & $\begin{array}{l}\text { Shanghai, China, } \\
1978\end{array}$ & Jarvis et al. (1986) \\
\hline USDA 208 & 6219 & & Glycine $\max$ & Honan, China & LMG \\
\hline \multicolumn{6}{|l|}{ Sinorhizobium meliloti } \\
\hline NZP 4009 & 6130 & & Medicago sativa & Australia & LMG \\
\hline $\mathrm{NZP} 4027^{\mathrm{T}}$ & $6133^{\mathrm{T}}$ & ORS $665^{\mathrm{T}}$ & Medicago sativa & Virginia, USA & LMG \\
\hline $102 \mathrm{~F} 34$ & & ORS 620 & & & ORS \\
\hline L5-30 & & ORS 621 & & & ORS \\
\hline RCR 2011 & & ORS 634 & & & ORS \\
\hline 3DOa30 & 4266 & & Medicago sativa & Turkey, 1952 & LMG \\
\hline \multicolumn{6}{|l|}{ Sinorhizobium medicae } \\
\hline HAMBI 1808 (m75) & 16579 & & Medicago sativa & & Eardly et al. (1990) \\
\hline HAMBI 1809 (m 102) & 16580 & ORS 504 & Medicago sativa & & Eardly et al. (1990) \\
\hline HAMBI 1837 (m158) & 16581 & & & & Eardly et al. (1990) \\
\hline \multicolumn{6}{|l|}{ Sinorhizobium terangae } \\
\hline ORS 15 & 7833 & & Sesbania sp. & Senegal & $\begin{array}{l}\text { de Lajudie et al. } \\
\text { (1994) }\end{array}$ \\
\hline ORS 51 & 7843 & & Sesbania rostrata & Senegal & $\begin{array}{l}\text { de Lajudie } \text { et al. } \\
\text { (1994) }\end{array}$ \\
\hline ORS 604 & 11865 & & Sesbania aculeata & Senegal & $\begin{array}{l}\text { de Lajudie et al. } \\
\text { (1994) }\end{array}$ \\
\hline ORS 1007 & 7847 & & Acacia laeta & Senegal & $\begin{array}{l}\text { de Lajudie et al. } \\
\text { (1994) }\end{array}$ \\
\hline ORS $1009^{\mathrm{T}}$ & $7834^{\mathrm{T}}$ & & Acacia laeta & Senegal & $\begin{array}{l}\text { de Lajudie et al. } \\
\text { (1994) }\end{array}$ \\
\hline ORS 1073 & 11926 & & Acacia senegal & Senegal & $\begin{array}{l}\text { de Lajudie et al. } \\
\text { (1994) }\end{array}$ \\
\hline \multicolumn{6}{|l|}{ Sinorhizobium saheli } \\
\hline ORS $609^{\mathrm{T}}$ & $7837^{\mathrm{T}}$ & & Sesbania cannabina & Senegal & $\begin{array}{l}\text { de Lajudie et al. } \\
\text { (1994) }\end{array}$ \\
\hline ORS $609 \mathrm{t} 2$ & $8309 \mathrm{t} 2$ & & Sesbania cannabina & Senegal & $\begin{array}{l}\text { de Lajudie et al. } \\
\text { (1994) }\end{array}$ \\
\hline ORS 611 & 7842 & & Sesbania grandiflora & Senegal & $\begin{array}{l}\text { de Lajudie et al. } \\
\text { (1994) }\end{array}$ \\
\hline ORS 611 & 8310 & & Sesbania grandiflora & Senegal & $\begin{array}{l}\text { de Lajudie et al. } \\
\text { (1994) }\end{array}$ \\
\hline \multicolumn{6}{|l|}{ Sinorhizobium $\mathrm{sp}$. } \\
\hline BR 816 & & ORS 2645 & & & ORS \\
\hline NGR 234 & & ORS 644 & Lablab purpureus & & Trinick (1980) \\
\hline \multicolumn{6}{|l|}{ Rhizobium leguminosarum } \\
\hline CNPAF 146 & 9504 & & & & LMG \\
\hline NZP 561 & 6122 & & Trifolium repens & Australia & B. Jarvis \\
\hline ATCC 14482 & $8819 t 1$ & & & & LMG \\
\hline \multicolumn{6}{|l|}{ Rhizobium tropici group a } \\
\hline CNPAF 119 & 9502 & & $\begin{array}{l}\text { Phaseolus vulgaris } \\
\text { L. }\end{array}$ & Brazil & LMG \\
\hline CFN 299 & 9517 & ORS 651 & $\begin{array}{l}\text { Phaseolus vulgaris } \\
\text { L. }\end{array}$ & Brazil & $\begin{array}{l}\text { Martínez-Romero } \\
\text { et al. (1991) }\end{array}$ \\
\hline
\end{tabular}


Table 1 (cont.)

\begin{tabular}{|c|c|c|c|c|c|}
\hline Strain* & LMG no. & $\begin{array}{l}\text { Other strain } \\
\text { designation }\end{array}$ & Host plant or origin & Geographical origin & Reference or source \\
\hline \multicolumn{6}{|c|}{ Rhizobium tropici group b } \\
\hline CIAT $899^{\mathrm{T}}$ & $9503^{\mathrm{T}}$ & ORS $1163^{\mathrm{T}}$ & $\begin{array}{l}\text { Phaseolus vulgaris } \\
\text { L. }\end{array}$ & Columbia & $\begin{array}{l}\text { Martínez-Romero } \\
\text { et al. }(1991)\end{array}$ \\
\hline C-05 & 9518 & & $\begin{array}{l}\text { Phaseolus vulgaris } \\
\text { L. }\end{array}$ & & $\begin{array}{l}\text { Martínez-Romero } \\
\text { et al. }(1991)\end{array}$ \\
\hline \multicolumn{6}{|l|}{ Rhizobium etli } \\
\hline $\mathrm{CFN} 42^{\mathrm{T}}$ & & ORS $645^{\mathrm{T}}$ & $\begin{array}{l}\text { Phaseolus vulgaris } \\
\text { L. }\end{array}$ & Mexico & $\begin{array}{l}\text { Segovia et al. } \\
\text { (1993) }\end{array}$ \\
\hline \multicolumn{6}{|l|}{ Rhizobium galegae } \\
\hline HAMBI $540^{\mathrm{T}}$ & $6214^{T}$ & ORS $668^{\mathrm{T}}$ & Galega orientalis & Finland & LMG \\
\hline HAMBI 1147 & 6215 & & Galega orientalis & Russia & LMG \\
\hline HAMBI $1428 / 2$ & 15143 & & Galega orientalis & Russia & LMG \\
\hline \multicolumn{6}{|l|}{ Agrobacterium bv. 2} \\
\hline ATCC $11325^{\mathrm{T}}$ & $150^{\mathrm{T}}$ & & & & \\
\hline \multicolumn{6}{|l|}{ Agrobacterium bv. 1} \\
\hline ATCC $19358^{\mathrm{T}}$ & $140^{\mathrm{T}}$ & ORS 1351 & & & LMG \\
\hline $\mathrm{M} 2 / 1$ & 147 & & Ditch water & Belgium & $\begin{array}{l}\text { Kersters et al. } \\
\text { (1973) }\end{array}$ \\
\hline B6 ${ }^{\mathrm{T}}$ & $187^{\mathrm{T}}$ & & $\begin{array}{r}\text { Lycopersicon } \\
\text { lycopersicon }\end{array}$ & USA & $\begin{array}{l}\text { Kersters et al. } \\
\text { (1973) }\end{array}$ \\
\hline ICPB TT111 & 196 & & Crown gall & USA & $\begin{array}{l}\text { Kersters et al. } \\
\text { (1973) }\end{array}$ \\
\hline $\mathrm{B} 2 \mathrm{a}$ & 268 & & $\begin{array}{r}\text { Lycopersicon } \\
\text { lycopersicon }\end{array}$ & & $\begin{array}{l}\text { Kersters et al. } \\
\text { (1973) }\end{array}$ \\
\hline IICHR 28 & 303 & & $\begin{array}{l}\text { Chrysanthemum } \\
\text { frutescens }\end{array}$ & Germany, 1927 & $\begin{array}{l}\text { Kersters et al. } \\
\text { (1973) }\end{array}$ \\
\hline CDC A 6597 & 383 & & Vagina & $\begin{array}{l}\text { South Carolina, } \\
\text { USA }\end{array}$ & LMG \\
\hline \multicolumn{6}{|l|}{ Agrobacterium rubi } \\
\hline ICPB TR2 & 159 & ORS 1353 & Rubus sp. & USA, 1942 & $\begin{array}{l}\text { Kersters et al. } \\
\text { (1973) }\end{array}$ \\
\hline ATCC $13335^{\mathrm{T}}$ & $156^{\mathrm{T}}$ & & Rubus ursinus & USA, 1942 & LMG \\
\hline \multicolumn{6}{|l|}{ Agrobacterium vitis } \\
\hline Pan. AG61 & 257 & ORS 2643 & Vitis vinifera & Crete, Greece & LMG \\
\hline Pan. AG63 & 258 & & Vitis vinifera & Crete, Greece & LMG \\
\hline NCPPB 1771 & 233 & & Vitis vinifera & Iran & $\begin{array}{l}\text { Kersters et al. } \\
\text { (1973) }\end{array}$ \\
\hline \multicolumn{6}{|c|}{ Azorhizohium caulinodans } \\
\hline ORS $571^{\mathrm{T}}$ & $6465^{\mathrm{T}}$ & & Sesbania rostrata & Senegal & $\begin{array}{l}\text { Dreyfus et al. } \\
\text { (1988) }\end{array}$ \\
\hline FY12 & 11352 & & Sesbania rostrata & Senegal & $\begin{array}{l}\text { Rinaudo et al. } \\
\text { (1991) }\end{array}$ \\
\hline
\end{tabular}

* Original strain number, or as received.

as follows: Acacia senegal, 14; Acacia seyal, 30; Acacia tortilis subsp. raddiana, 150; Sesbania rostrata, 30-60; Sesbania pubescens, 60; Sesbania grandiftora, 60; Neptunia natans, 30; Medicago sativa, 25; Macroptilium atropurpureum (Siratro), 3. For Vigna unguiculata (niebe), seeds were left for $3 \mathrm{~min}$ in $96 \%$ alcohol followed by $5 \mathrm{~min}$ in $1 \%$ $\mathrm{HgCl}_{2}$. After acid or $\mathrm{HgCl}_{2}$ treatment, the seeds were washed with water until all traces of acid or $\mathrm{HgCl}_{2}$ were removed.
The seeds were incubated in sterile Petri dishes on $1 \%$ water agar for $24-48 \mathrm{~h}$ to allow germination and then transferred to tubes containing Jensen seedling slant agar (Vincent, 1970) for root nodulation trials (8-10 plants were routinely tested with each strain). Root nodules appeared around 10-20 d after inoculation, and 3 weeks later they were fully developed. Nitrogen-fixing potential was estimated by visual observation of plant vigour and foliage colour of 30 - to 45 - 
d-old plants and also by measuring the fresh and dry weights of aerial parts; infected plants were compared with control uninoculated plants.

PAGE of total bacterial proteins. PAGE was performed using small modifications of the procedure of Laemmli (1970), as described previously (de Lajudie et al., 1994). The normalized densitometric traces of the protein electrophoretic patterns were grouped by numerical analysis, using the GelCompar 2.2 software package (Vauterin \& Vauterin, 1992). Similarity between pairs of traces was expressed by the Pearson product-moment correlation coefficient $(r)$ converted for convenience to a percentage value (Pot et al., 1989, 1994).

PCR-RFLP of the ITS of 16S-23S rRNA genes. Strains were grown at $28{ }^{\circ} \mathrm{C}$ for $36-48 \mathrm{~h}$ on YMA, according to the method of Vincent (1970). Total DNA was purified with Chelex 100 (Sigma). Cells resuspended in a 5\% suspension of Chelex 100 were boiled for $15 \mathrm{~min}$. After centrifugation, the supernatant was used directly for PCR amplification. For strains for which the above procedure did not result in optimum DNA amplification, total DNA was purified using the phenol-chloroform method as described by Boucher et al. (1987). Primers FGPL $132^{\prime}-38$ and FGPS 1490-72, as described by Normand et al. (1996), were used for PCR amplification. These primers are derived from conserved regions of the $23 \mathrm{~S}$ and $16 \mathrm{~S}$ rRNA genes, respectively, and can be used to amplify the ITS of all prokaryotic DNAs tested so far. The oligonucleotides were purchased from Pharmacia. PCR amplification was carried out in a $100 \mu \mathrm{l}$ reaction volume containing template DNA $(50 \mu \mathrm{g})$, reaction buffer (Appligene), $20 \mathrm{mM}$ of each dNTP (Pharmacia), $0.1 \mathrm{mM}$ of each of the primers and $1 \mathrm{U}$ Taq polymerase (Appligene). Amplifications were carried out in a GeneAmp PCR System 2400 (Perkin Elmer) using the following programme: initial denaturation for $5 \mathrm{~min}$ at $94^{\circ} \mathrm{C}, 35$ cycles of denaturation $\left(30 \mathrm{~s}\right.$ at $94^{\circ} \mathrm{C}$ ), annealing $(30 \mathrm{~s}$ at $\left.55^{\circ} \mathrm{C}\right)$ and extension $\left(1 \mathrm{~min}\right.$ at $\left.72^{\circ} \mathrm{C}\right)$ and a final extension $\left(5 \mathrm{~min}\right.$ at $\left.72^{\circ} \mathrm{C}\right)$. PCR-amplified DNAs were visualized by electrophoresis of $4 \mu \mathrm{l}$ of the amplified mixture on $1.4 \%$ $(\mathrm{w} / \mathrm{v})$ horizontal agarose gel (type 11 ; Sigma) in TBE buffer ( $83 \mathrm{mM}$ Tris base, $89 \mathrm{mM}$ boric acid, $2 \mathrm{mM}$ EDTA, pH 8.0) at $4 \mathrm{~V} \mathrm{~cm}^{-1}$ for $1 \mathrm{~h}$. The gels were stained in an aqueous solution of $1 \mathrm{mg}$ ethidium bromide $1^{-1}$ and photographed with Polaroid Type 667 positive film using a $260 \mathrm{~nm}$ UV source.

Aliquots of $6 \mu \mathrm{l}$ of PCR products were digested in a $10 \mu \mathrm{l}$ final volume with restriction endonucleases as specified by the manufacturer but with an excess of enzyme ( $5 \mathrm{U}$ per reaction). The following enzymes were used: $A l u \mathrm{I}, D d e \mathrm{I}$, Hinf I, Pal I (Pharmacia), Cfo I (Boehringer Mannheim), Msp I (Gibco-BRL), Rsa I (Amersham or Gibco-BRL). Restricted DNA was analysed by horizontal electrophoresis in $3 \%(\mathrm{w} / \mathrm{v})$ agarose gel (Nusieve $3: 1$; FMC). Electrophoresis was run at $2 \cdot 3 \mathrm{~V} \mathrm{~cm}^{-1}$ for $3 \mathrm{~h}$. Gels were stained and photographed as described previously.

Clustering was obtained using the GelCompar 2.2 software package (Vauterin \& Vauterin, 1992).

DNA base composition. Cells were grown for $2-3 \mathrm{~d}$ in Roux flasks on TY medium. High-molecular-mass DNA was prepared using the method of Marmur (1961). The G+C content was determined by thermal denaturation (De Ley, 1970) and calculated by using the equation of Marmur \& Doty (1962), as modified by De Ley (1991). DNA from Escherichia coli $\mathrm{LMG} 2093$ was used as a reference.
DNA-DNA hybridization. DNA-DNA hybridizations were performed with the initial renaturation rate method (De Ley, 1970). Renaturations using approximately $50 \mathrm{mg}$ DNA $\mathrm{ml}^{-1}$ were carried out at $79 \cdot 8^{\circ} \mathrm{C}$, which is the optimum renaturation temperature, in $2 \times \mathrm{SSC}(1 \times \mathrm{SSC}=0.15 \mathrm{M}$ $\mathrm{NaCl}, 0 \cdot 015 \mathrm{M}$ sodium citrate, $\mathrm{pH}$ 7).

Analysis of the 16S rRNA genes. The nearly complete $16 \mathrm{~S}$ rRNA gene of strain LMG 11875, a representative of the new group, was determined. Lyophilized cells were resuspended in $500 \mathrm{ml}$ TES buffer $(0.05 \mathrm{M}$ Tris/ $\mathrm{HCl}, 0.005 \mathrm{M}$ EDTA, 0.05 M NaCl, pH 8.0) and DNA was extracted by the method of Lawson et al. (1989). A large fragment of the 16S rRNA gene (corresponding to positions 28-1521 of the Escherichia coli $16 \mathrm{~S}$ rRNA gene) was amplified by PCR. The PCR products were purified using a Prep-A-Gene kit (BioRad) and sequenced using a Taq DyeDeoxy Terminator Cycle Sequencing Kit (Applied Biosystems) and an automatic DNA sequencer (model 373A; Applied Biosystems). The new sequence was aligned, together with reference sequences obtained from the EMBL database, using the program PILEUP of the Genetics Computer Group package (Devereux et al., 1984). Altogether a continuous stretch of 1348 base positions (including gaps) was used for further analysis. This corresponded to positions 84-1480 of the Escherichia coli $16 \mathrm{~S}$ rRNA gene. Distances, modified according to the Kimura-2 model, were calculated using the DNADIST program of the Phylogeny Inference Package (Felsenstein, 1982), and the program NEIGHBOR of the same package was used to produce an unrooted phylogenetic tree. The stability of the groupings was verified by bootstrap analysis (500 replications) using the programs DNABOOT, DNADIST, NEIGHBOR and CONSENSE (Felsenstein, 1982). Uncorrected distances were calculated using the DISTANCES program of the GCG package and used to calculate similarity values.

Auxanographic tests. API galleries (API $50 \mathrm{CH}$, API $50 \mathrm{AO}$ and API 50AA; bioMérieux) were used to test the assimilation of 147 organic compounds as sole carbon sources, and the results of auxanographic tests were scored as described previously (de Lajudie et al., 1994).

3-Ketolactose test. The 3-ketolactose test was performed using the original method of Bernaerts \& De Ley (1963) as modified by Bouzar et al. (1995).

\section{RESULTS}

Six isolates were purified from root nodules collected either on $N$. natans plants growing naturally in waterlogged areas around the town of Kaolack in the Sine Saloum region of Senegal or on $N$. natans plants seeded in our experimental field at Dakar-Bel Air in Senegal.

\section{Host specificity}

The six Neptunia isolates induced nodules on their original host, resulting in a very efficient nitrogenfixing symbiosis. They were also found to be effective on Acacia species (Acacia tortilis subsp. raddiana, Acacia senegal, Acacia seyal), Faidherbia albida, and some strains were effective on Lotus arabicus, but ineffective on Medicago sativa, Sesbania species (Sesbania rostrata, Sesbania pubescens, Sesbania gran- 
Table 2. Host specificity of $N$. natans isolates

All strains nodulated $N$. natans, Acacia seyal, Faidherbia albida and Acacia tortilis subsp. raddiana. No strain nodulated Sesbania rostrata, Sesbania pubescens or Sesbania grandiflora.

\begin{tabular}{|lccccc|}
\hline Strain & $\begin{array}{c}\text { Acacia } \\
\text { senegal }\end{array}$ & $\begin{array}{c}\text { Lotus } \\
\text { arabicus }\end{array}$ & $\begin{array}{c}\text { Medicago } \\
\text { sativa }\end{array}$ & $\begin{array}{c}\text { Vigna } \\
\text { unguiculata }\end{array}$ & $\begin{array}{c}\text { Macroptilium } \\
\text { atropurpureum }\end{array}$ \\
\hline ORS 991 & + & \pm & \pm & NT & NT \\
ORS 992 & NT & - & - & - & - \\
ORS 995 & NT & \pm & - & NT & NT \\
ORS 996 & NT & + & - & NT & NT \\
ORS 997 & + & + & - & - & - \\
ORS 998 & + & - & - & NT & NT \\
\hline
\end{tabular}

+ , Nodulation; - , no nodulation;, $\pm 10-30 \%$ plants were nodulated; NT, not tested.
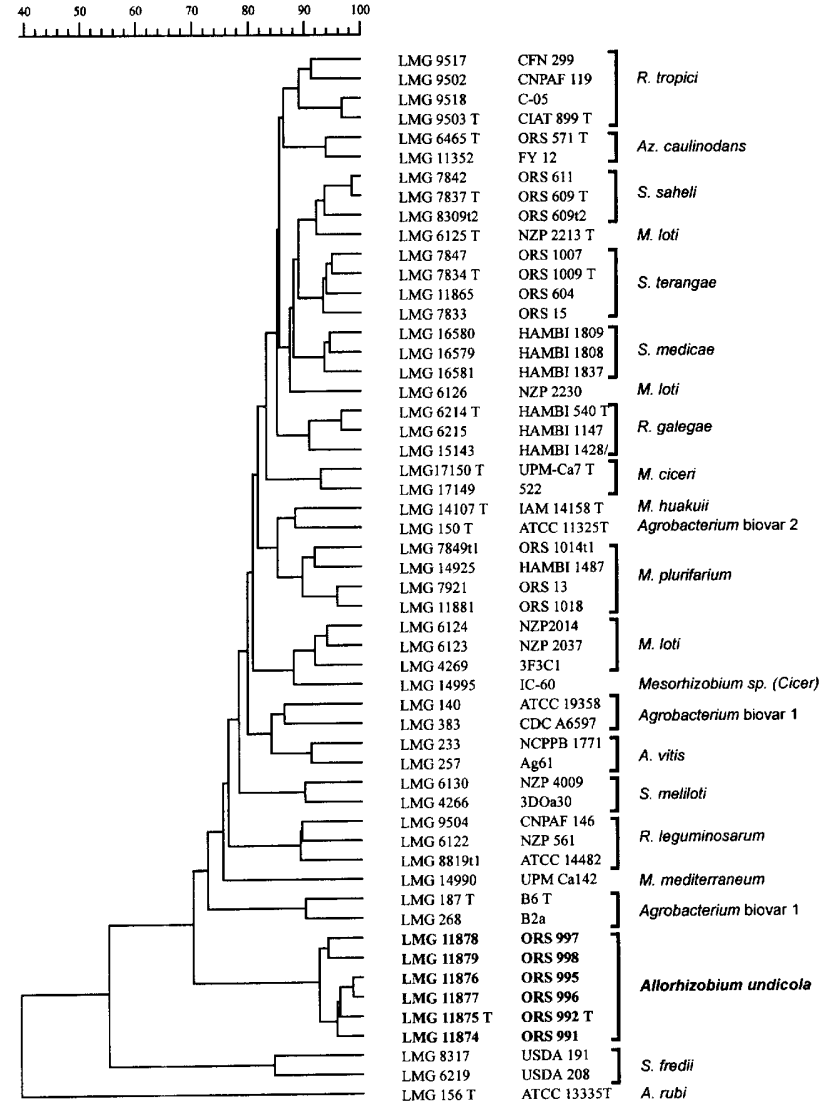

Fig. 1. Dendrogram showing the relationships between the electrophoretic protein patterns from nodule isolates of $N$. natans and reference strains of Mesorhizobium, Rhizobium, Bradyrhizobium, Azorhizobium, Sinorhizobium and Agrobacterium species. The mean correlation coefficient $(r)$ was represented as a dendrogram and calculated by the unweighted pair group method with averages. Positions 10-320 of the 400 point traces were used for calculation of similarities between individual pairs of traces. $T$ indicates type strain. The scale represents the $r$ values converted to percentages.

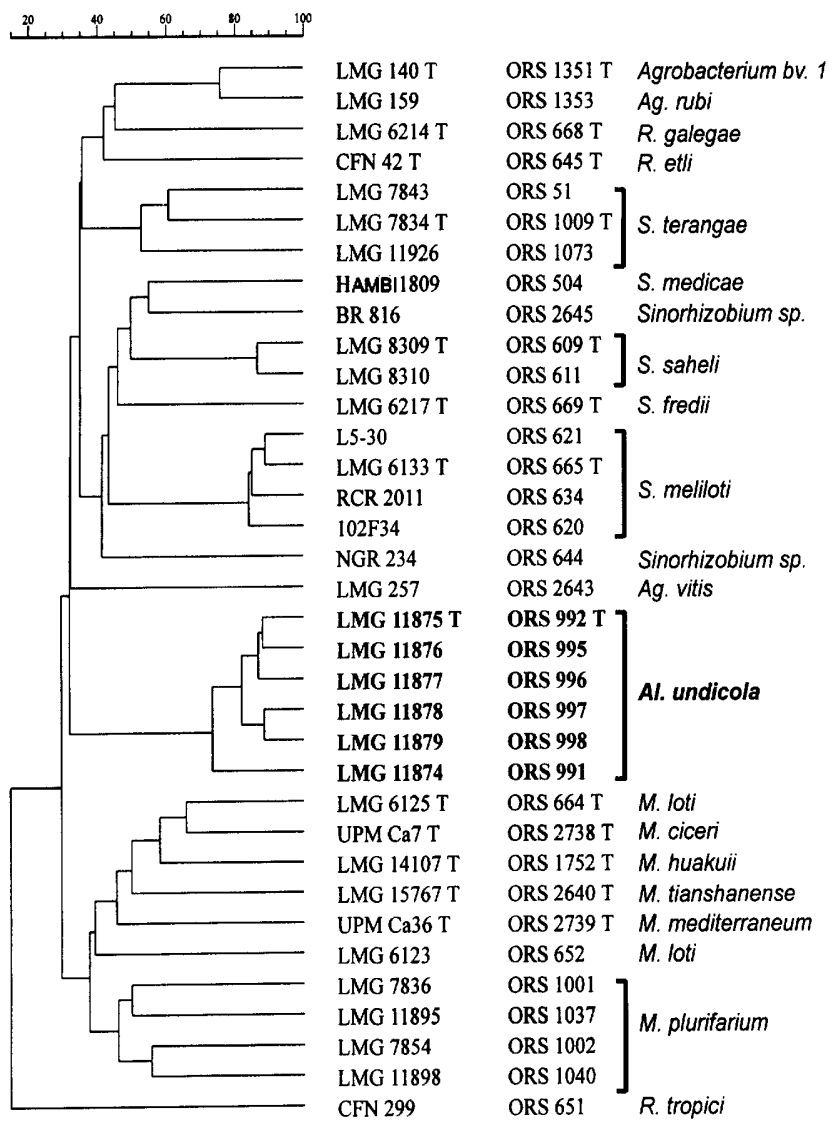

Fig. 2. Dendrogram showing the relationships between the PCR-RFLP profiles of the ITS of $N$. natans nodule isolates and representatives of different Mesorhizobium, Rhizobium, Bradyrhizobium, Azorhizobium, Sinorhizobium and Agrobacterium species. The mean correlation coefficient $(r)$ was represented as a dendrogram and calculated by the unweighted pair group method with averages. $T$ indicates type strain. The scale represents the $r$ value converted to percentages. 


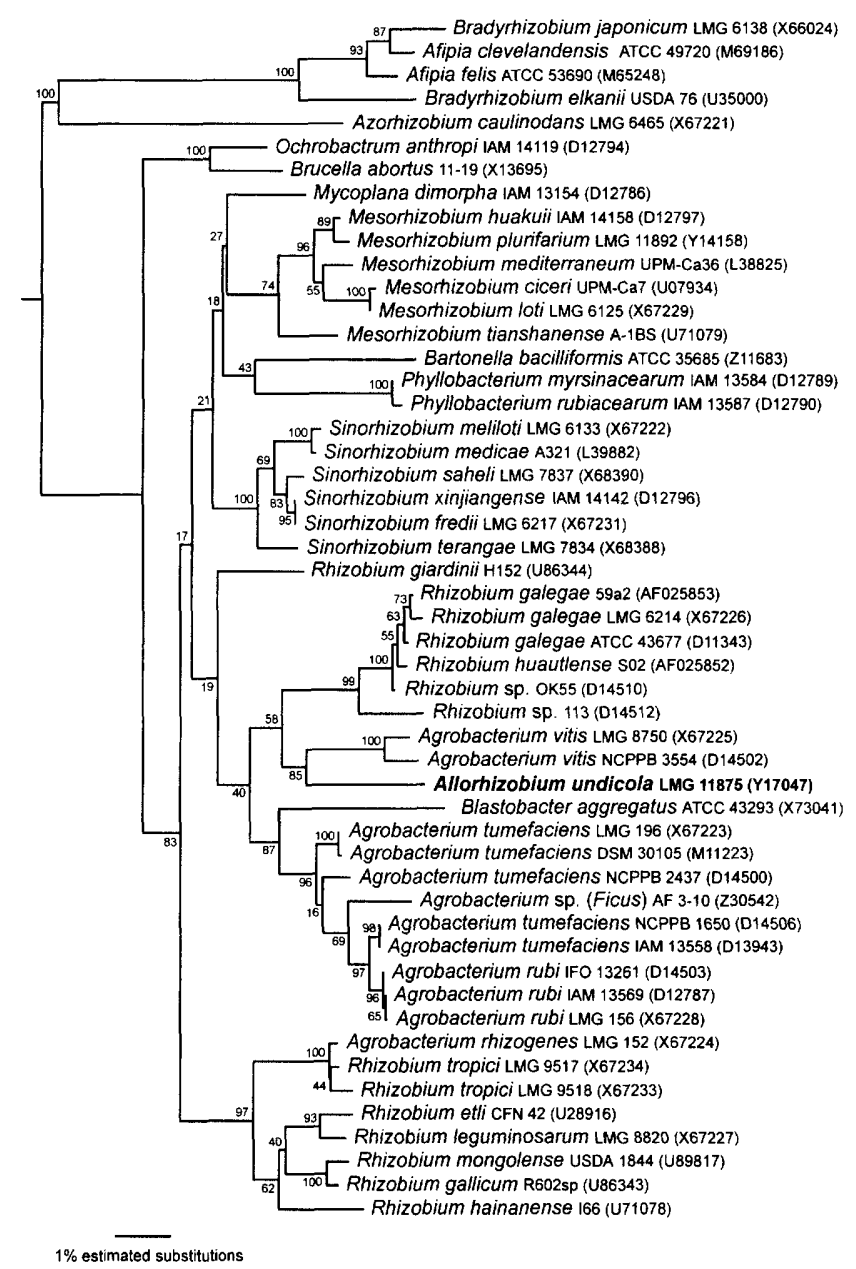

Fig. 3. Dendrogram showing the phylogenetic relationships of strain LMG 11875 and representatives of the alpha subclass of the Proteobacteria. The tree was calculated from a distance matrix (modified according to the Kimura-2 model) using the neighbour-joining method. Bootstrap values, expressed as a percentage of 500 replications, are given at the branching points. Numbers in parentheses are the accession numbers of the sequences used. The bar represents one expected substitution per 100 nucleotide positions.

diflora), Vigna unguiculata and Macroptilium atropurpureum (Table 2).

\section{SDS-PAGE of total bacterial proteins}

We purified whole-cell proteins from the $N$. natans isolates, performed SDS-PAGE in standardized conditions (de Lajudie et al., 1994) and compared the normalized patterns (Vauterin \& Vauterin, 1992) with those in our database, which contains profiles of strains of different species of Rhizobium, Sinorhizobium, Mesorhizobium, Agrobacterium and Azorhizobium. Sinorhizobium terangae, Sinorhizobium saheli, Sinorhizobium fredii, Sinorhizobium meliloti, Sinorhizobium medicae, Rhizobium leguminosarum, Rhizobium tropici, Rhizobium galegae, Azorhizobium caulinodans, Mesorhizobium plurifarium, Mesorhizobium ciceri, Meso-

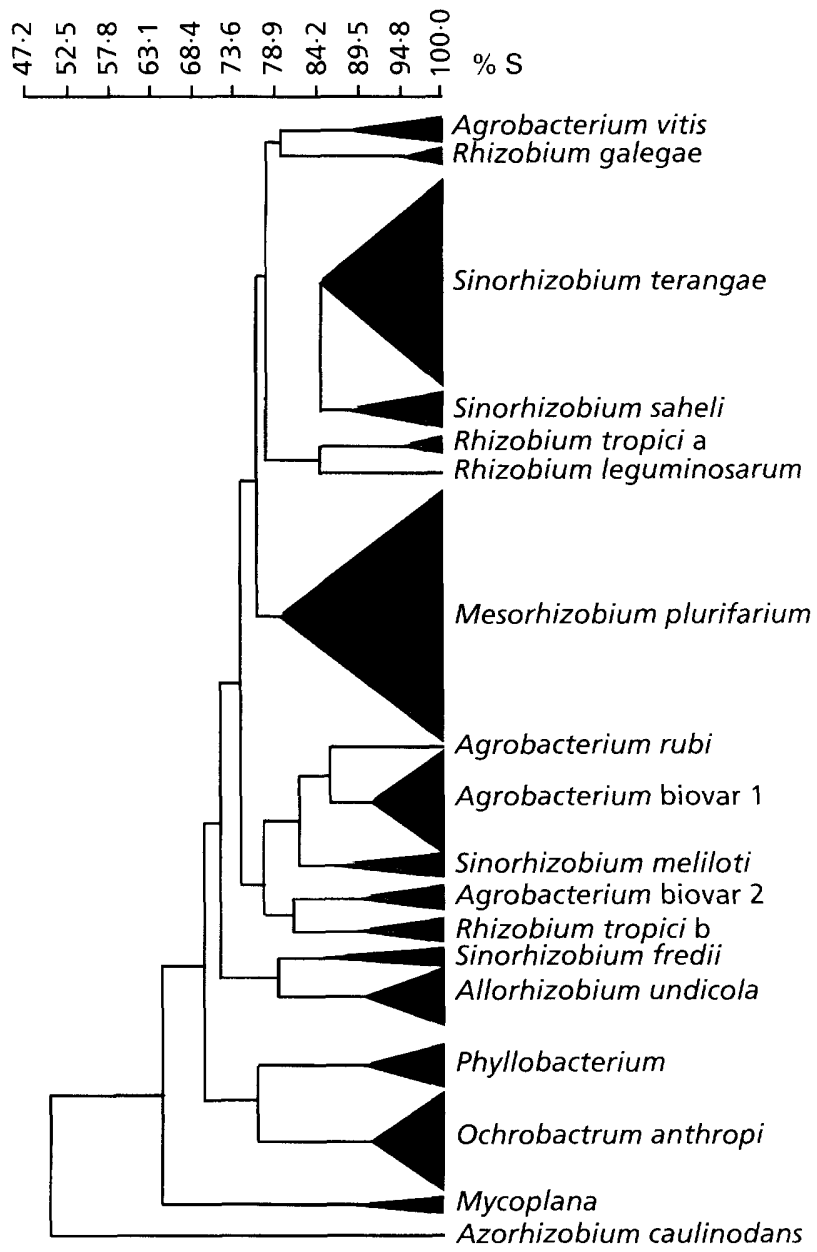

Fig. 4. Dendrogram obtained from an unweighted pair group method with averages cluster analysis of Canberra metric similarity coefficients based on 147 auxanographic characteristics. Reference strains included in this study were essentially the same as those we used in a previous report (de Lajudie et al., 1994). Numbers of strains used were as follows: Agrobacterium bv. 1, 9; Agrobacterium bv. 2, 3; Agrobacterium rubi, 1; Agrobacterium vitis, 3; Rhizobium galegae, 2; Sinorhizobium meliloti, 3; Sinorhizobium fredii, 2; Sinorhizobium terangae, 20; Sinorhizobium saheli, 4; Rhizobium leguminosarum, 1; Rhizobium tropici a, 3; Rhizobium tropici b, 3; Mesorhizobium plurifarium, 26; Azorhizobium caulinodans, 1; Phyllobacterium, 5; Ochrobactrum anthropi, 10; Mycoplana, 2.

rhizobium sp. (Cicer) formed separate clusters. This is illustrated in Fig. 1, which presents a limited dendrogram with a few representatives of the different species. Only one strain each of Mesorhizobium huakuii, Mesorhizobium mediterraneum, Agrobacterium bv. 2, Agrobacterium vitis and Agrobacterium rubi were included, and these each had separate positions. Strains of Agrobacterium bv. 1 exhibited diverse protein patterns and could be grouped into two different clusters, as observed previously (de Lajudie $e t$ al., 1998). The strains of Mesorhizobium loti did not group together and were found to fall into three clusters. The six $N$.natans isolates were related with a 
correlation coefficient of $92 \%$ and formed a rather homogeneous gel electrophoretic cluster, distinct from all described species and clusters contained in our database. The highest correlation coefficient between the cluster of Neptunia strains and the other rhizobial species and groups was $70 \%$.

\section{PCR-RFLP of the ITS}

We performed PCR-RFLP analysis of the ITS region between the 16S and 23S rRNA genes of the Neptunia strains and some representative strains of rhizobial species of Rhizobium, Sinorhizobium, Mesorhizobium and Agrobacterium. The size of the amplified ITS fragment varied from 1000 to $1450 \mathrm{bp}$ depending on strains and was $1380-1390$ bp for the Neptunia isolates. The results of RFLP analysis are shown in Fig. 2. All strains belonging to the same species, except Mesorhizobium loti, grouped together. At a correlation coefficient of $30 \%$, three main branches could be distinguished. The first branch consisted of the Rhizobium, Sinorhizobium and Agrobacterium species, together with two Sinorhizobium sp. strains, BR 816 and NGR 234. The second branch consisted of the Mesorhizobium species (Mesorhizobium loti, Mesorhizobium huakuii, Mesorhizobium ciceri, Mesorhizobium tianshanense, Mesorhizobium mediterraneum, Mesorhizobium plurifarium). All isolates from $N$. natans could be grouped in a third branch as a separate homogeneous group (internal correlation coefficient of $73 \%$ ) distinct from every other described species.

\section{G + C content of DNA and DNA-DNA hybridizations}

The $\mathrm{G}+\mathrm{C}$ content of ORS $992^{\mathrm{T}}$ is $60.1 \mathrm{~mol} \%$. We found a high degree of DNA-DNA binding $(89 \%)$ between two strains (ORS $992^{\mathrm{T}}$ and ORS 997) of the new $N$. natans group.

\section{Analysis of the 165 rRNA genes}

The determined sequence of the 16S rRNA gene of strain LMG 11875 consisted of 1433 bases. A search in the EMBL database revealed the new sequence to be most similar to the 16S rRNA gene sequence of Agrobacterium vitis, thereby placing the new isolates in the Rhizobium-Agrobacterium group of the alpha subclass of the Proteobacteria. A dendrogram showing the phylogenetic relationships of strain LMG 11875 and representatives of the alpha subclass of the Proteobacteria is shown in Fig. 3.

\section{Numerical analysis of auxanographic results}

The six Neptunia isolates were tested for assimilation of 147 organic compounds as sole carbon source using the API 50) system, and the results were compared with those of representative strains of Sinorhizobium fredii, Sinorhizohium meliloti, Sinorhizobium terangae, Sinorhizobium saheli, Mesorhizobium loti, Mesorhizobium huakuii, Mesorhizobium plurifarium, Rhizobium leguminosarum, Rhizobium tropici, Rhizobium galegae,
Agrobacterium rhizogenes, Agrobacterium tumefaciens, Agrobacterium vitis, Agrobacterium rubi, Azorhizobium caulinodans, Ochrobactrum, Phyllobacterium and $M y$ coplana available in our database (de Lajudie et al., 1994). The dendrogram obtained by numerical analysis of these results (Fig. 4) showed that the Neptunia strains formed a very homogeneous group distinct from every other species. They were related to Agrobacterium vitis at a correlation coefficient of 0.695 . Table 3 shows the results of the Neptunia strains and their nearest phylogenetic relatives, namely Agrobacterium vitis, Agrobacterium bv. 1, Agrobacterium rubi and Rhizobium galegae.

\section{3-Ketolactose test}

The six strains from Neptunia were negative, as were the four control strains of Agrobacterium bv. 2 tested (LMG 150 ${ }^{\mathrm{T}}$, LMG 155, LMG 161, LMG 341). Control Agrobacterium bv. 1 strains LMG 64, LMG 146, LMG 196, LMG 201, LMG 296t2 were positive; Agrobacterium bv. 1 strain LMG 26 and Agrobacterium sp. strain LMG 294 were negative.

\section{DISCUSSION}

We isolated six new strains from naturally occurring nodules of Neptunia natans plants in Senegal. These strains grew rapidly on YMA, produced exopolysaccharides and exhibited a particular spectrum of carbon source utilization. We employed a polyphasic approach to the taxonomic characterization of this new group of tropical rhizobia, using techniques with wide discriminative powers (16S rRNA gene sequencing and auxanography) and others at the species and infra-species levels (DNA-DNA hybridization, SDSPAGE, PCR-RFLP of the ITS). Two screening methods, SDS-PAGE protein profile analysis and numerical analysis of auxanographic data, indicated that these isolates constitute a homogeneous phenon, distinct from a wide range of rhizobia, agrobacteria and other related bacteria (Figs 1 and 4). These results suggested that this group constituted a separate species, which we further characterized using genotypic techniques with diverse taxonomic discriminative powers.

PCR-RFLP analysis of the ITS of $16 \mathrm{~S}-23 \mathrm{~S}$ genes demonstrated that the new Neptunia isolates constitute a homogeneous genotypic group (Fig. 2), and this was further supported by the high level of DNA-DNA binding $(89 \%)$ found between two representative strains. Our RFLP analysis of the 16S-23S ITS confirmed that the new group is also genotypically distinct from representatives of all known species of the Rhizobium-Agrobacterium group (Fig. 2). To determine precisely the phylogenetic position of the Neptunia natans isolates, the 16S rRNA gene sequence of a representative strain (LMG 11875) was determined. Phylogenetic analysis revealed that this strain is related to the Agrobacterium lineage that contains 
Table 3. Results of carbon assimilation tests performed with Allorhizobium undicola and reference strains of Rhizobium galegae, Agrobacterium bv. 1, Agrobacterium vitis and Agrobacterium rubi

$n=$ Number of strains studied; results recorded for strains Agrobacterium vitis LMG 257 and LMG 258, Allorhizobium undicola ORS 991, ORS 992 ${ }^{\mathrm{T}}$, ORS 995, ORS 996, ORS 997 and ORS 998, Rhizobium galegae LMG 6214 ${ }^{\mathrm{T}}$ and LMG 6215, Agrobacterium bv. 1 LMG 140, LMG 147, LMG 187", LMG 196, LMG 268, LMG 303, LMG 383 and Agrobacterium rubi LMG 156 ${ }^{\mathrm{T}}$. +, All strains are positive; - , all strains are negative; the values are the percentage of positive strains. The main discriminative results between Allorhizobium undicola and Agrobacterium vitis are given in bold face. The reaction of the type strain is given in parentheses. All strains grew in API 50 on glycerol, ribose, L-arabinose, D-xylose, D-galactose, D-glucose, D-fructose, D-mannose, D-cellobiose, D-maltose, lactose, rhamnose, D-turanose, D-lyxose, inositol, mannitol, D-arabitol, fumarate, DL-lactate, D-malate, L$(\alpha)$-alanine, L-proline and L-histidine and did not grow on erythritol, aesculin, inulin, starch, glycogen, isobutyrate, $n$-valerate, isovalerate, $n$-caproate, heptanoate, caprylate, pelargonate, caprate, maleate, oxalate, adipate, pimelate, suberate, azelate, sebacate, glycolate, laevulinate, citraconate, itaconate, mesaconate, phenylacetate, benzoate, $o$-hydroxybenzoate, D-mandelate, Lmandelate, phthalate, isophthalate, terephthalate, glycine, DL-norvaline, DL-2-aminobutyrate, L-methionine, L-phenylalanine, Ltyrosine, D-tryptophan, L-tryptophan, DL-kynurenine, creatine, urea, acetamide, ethylamine, butylamine, amylamine, benzylamine, diaminobutane, spermine, histamine and tryptamine.

\begin{tabular}{|c|c|c|c|c|c|}
\hline Substrate & $\begin{array}{l}\text { Ag. vitis } \\
(n=2)\end{array}$ & $\begin{array}{l}\text { Al. undicola } \\
(n=6)\end{array}$ & $\begin{array}{l}\text { R. galegae } \\
(n=2)\end{array}$ & $\begin{array}{l}\text { Ag. bv. } 1 \\
(n=7)\end{array}$ & $\begin{array}{l}\text { Ag. rubi } \\
(n=1)\end{array}$ \\
\hline $\begin{array}{l}\text { Dulcitol, methyl } \alpha \text {-D-glucoside, D-melezitose, D-tagatose, L- } \\
\text { arabitol, 5-ketogluconate, propionate, aconitate, L-lysine, L- } \\
\text { citrulline, sarcosine, ethanolamine }\end{array}$ & - & - & - & + & + \\
\hline Methyl $\alpha$-D-xyloside, xylitol & - & - & + & + & + \\
\hline D-Tartrate, mesotartrate, $m$-hydroxybenzoate & - & - & + & - & - \\
\hline Arbutin & + & + & - & + & + \\
\hline L-Ornithine & - & + & - & + & + \\
\hline $\begin{array}{l}\text { DL-Glycerate, adonitol, } N \text {-acetylglucosamine, D-melibiose, } \\
\text { gluconate, D-raffinose, L-fucose }\end{array}$ & + & - & + & + & + \\
\hline L-Tartrate, citrate & + & - & - & - & - \\
\hline Glutarate & + & - & - & 50 & - \\
\hline Butyrate & + & - & 50 & - & - \\
\hline Malonate & - & - & - & - & + \\
\hline L-Sorbose & - & - & - & 75 & + \\
\hline D-Arabinose, 2-ketogluconate & 50 & - & + & + & + \\
\hline Methyl $\alpha$-D-mannoside & 50 & - & - & - & - \\
\hline Amygdalin & 50 & - & - & + & + \\
\hline L-Xylose & 50 & - & - & 50 & - \\
\hline$\beta$-Gentiobiose & 50 & + & + & + & + \\
\hline Sorbitol, acetate & + & $85(+)$ & + & + & + \\
\hline Salicin & + & $75(+)$ & - & + & + \\
\hline Trehalose, D-fucose & + & $30(-)$ & + & + & + \\
\hline Succinate & + & $60(+)$ & + & + & + \\
\hline Sucrose, DL-3-hydroxybutyrate, L-malate & + & $80(+)$ & + & + & + \\
\hline Pyruvate & + & + & + & 75 & + \\
\hline 2-Ketoglutarate & - & $30(-)$ & - & 50 & + \\
\hline$p$-Hydroxybenzoate & + & $80(+)$ & + & 75 & + \\
\hline L-Leucine & - & - & 50 & 25 & - \\
\hline L-Isoleucine, L-valine & - & - & - & 25 & - \\
\hline $\mathrm{D}-(\alpha)$-Alanine, L-norleucine & - & - & - & 50 & - \\
\hline L-Cysteine & - & - & - & 75 & - \\
\hline L-Serine, L-threonine & 50 & + & - & + & + \\
\hline Trigonelline & + & $30(-)$ & - & 25 & - \\
\hline L-Aspartate & + & $30(-)$ & - & + & + \\
\hline L-Glutamate & 50 & + & - & + & + \\
\hline L-Arginine & - & $60(-)$ & - & + & + \\
\hline Betaine & 50 & $30(+)$ & + & + & + \\
\hline$\beta$-Alanine & - & $60(+)$ & - & 50 & + \\
\hline DL-3-Aminobutyrate & - & $30(+)$ & - & - & - \\
\hline DL-4-Aminobutyrate & + & $80(+)$ & - & 75 & + \\
\hline DL-5-Aminovalerate & - & $30(+)$ & - & 25 & + \\
\hline 2-Aminobenzoate, 3-aminobenzoate, 4-aminobenzoate & - & $15(-)$ & - & - & - \\
\hline Glucosamine & + & $60(-)$ & + & 75 & + \\
\hline
\end{tabular}


Table 4. Discriminatory utilization of carbohydrates as sole carbon source in Allorhizobium and other related genera and phylogenetic groups

Results from this work, de Lajudie et al. (1994, 1998), Nour et al. (1994, 1995) and Chen et al. (1991, 1995). +, All strains are positive; - , all strains are negative; $d$, some strains are positive.

\begin{tabular}{|c|c|c|c|c|c|c|c|c|}
\hline Carbohydrate & Allorhizobium & $\begin{array}{c}\text { Agrobacterium } \\
\text { bv. } 1\end{array}$ & $\begin{array}{c}\text { Rhizobium } \\
\text { vitis }\end{array}$ & $\begin{array}{c}\text { Rhizobium } \\
\text { galegae }\end{array}$ & Rhizobium $^{*}$ & Sinorhizobium $\dagger$ & Mesorhizobium $\ddagger$ & Azorhizobium \\
\hline Adonitol & - & + & + & + & + & + & + & - \\
\hline D-Arabinosc & - & + & $\mathrm{d}$ & + & + & $\mathrm{d}$ & d & - \\
\hline L-Fucose & - & + & + & + & + & $\mathrm{d}$ & d & - \\
\hline$N$-Acetylglucosamine & - & + & + & + & $\mathrm{d}$ & + & + & - \\
\hline D-Melibiose & - & + & + & + & + & + & d & - \\
\hline D-Raffinose & - & + & + & + & + & + & d & - \\
\hline Trehalose & $\mathrm{d}$ & + & + & + & + & + & + & - \\
\hline Methyl xyloside & - & + & - & + & + & d & - & - \\
\hline Sucrose & $\mathrm{d}$ & + & + & + & + & + & $\mathrm{d}$ & - \\
\hline Xylitol & - & + & - & + & + & $d$ & $d$ & - \\
\hline L-Arabitol & - & + & - & - & + & d & d & - \\
\hline Gluconate & - & + & + & + & + & d & d & + \\
\hline Succinate & $\mathrm{d}$ & + & + & + & d & + & + & + \\
\hline DL-glycerate & - & + & + & + & d & d & d & + \\
\hline
\end{tabular}

* Results for Rhizobium tropici, Rhizobium leguminosarum and Agrobacterium bv. 2.

$\uparrow$ Results for Sinorhizobium fredii, Sinorhizobium terangae, Sinorhizobium saheli and Sinorhizobium meliloti.

$\ddagger$ Results for Mesorhizobium loti, Mesorhizobium huakuii, Mesorhizobium ciceri, Mesorhizobium mediterraneum, Mesorhizobium tianshanense and Mesorhizobium plurifarium.

Agrobacterium tumefaciens bv. 1, Agrobacterium rubi, Agrobacterium strains isolated from Ficus, Agrobacterium vitis and Rhizobium galegae (Fig. 3). Sequence similarity values of members of this lineage with strain LMG 11875 ranged from 94.5 to $95 \cdot 2 \%$, with the highest value found between this strain and Agrobacterium vitis strain LMG 8750 (96.3\% sequence similarity. corresponding to at least 55 base differences). From the level of these similarity values, it can be presumed that there is no significant DNADNA binding between these groups of organisms; in consequence, and following the recommendation of Stackebrandt \& Goebel (1994), no additional DNADNA hybridizations were performed.

The results of all the techniques used converge to the conclusion that the new isolates from $N$. natans nodules form a homogeneous group that can be phenotypically and genotypically distinguished from other described species of rhizobia and agrobacteria. It is clear that this taxon represents at least a new species. The genus allocation of this group is less clear-cut and several possibilities are apparent:

(i) The new group could be described as a new Rhizobium species, because it lives in a nitrogen-fixing symbiosis with leguminous plants and is phylogenetically related to Rhizobium galegae (Fig. 3, sequence similarity $95 \cdot 1 \%$ ). However, it is clear that both the new group and Rhizobium galegae are phylogenetically distinct from the lineage that contains the type species of the genus Rhizobium, Rhizobium leguminosarum, and therefore represents the true genus Rhizobium (Fig. 3, sequence similarity of the Rhizobium leguminosarum lineage with strain LMG 11875 ranges from 92.9 to $93.5 \%$ ). Furthermore, several other genera [Agrobacterium (94.5-96.3\% sequence similarity, Sinorhizobium $(94 \cdot 2 \%$ sequence similarity with Sinorhizobium fredii) and Mesorhizobium (93.1\% sequence similarity with Mesorhizobium loti)] are also closely related to the new group. The proposal of a new Rhizobium species for the Neptunia isolates is thus excluded on phylogenetic grounds.

(ii) The new group could be described as a new Agrobacterium species, because phylogenetically it belongs to the bv. 1 Agrobacterium lineage, which contains the type strain of the type species of the genus Agrobacterium. However, it is generally recognized that the species delineation in this genus is unclear and needs revision. Although the new group is clearly distinct from all other Agrobacterium species in the bv. 1 lineage (Fig. 3), the peripheral position of Agrobacterium vitis in this lineage and the presence of Rhizobium galegae, together with the low bootstrap values (Fig. 3), indicate that this lineage may represent several genera, and it therefore seems unwise to create a new Agrobacterium species in this group. In addition to these phylogenetic considerations, the inclusion of a non-tumorigenic species in the genus Agrobacterium would undoubtedly raise opposition from phytopathologists and lead to considerable practical problems.

(iii) The new group could be described as a new genus of nitrogen-fixing legume symbionts. It is most closely related to Rhizobium galegae and Agrobacterium vitis, but the 16S rRNA gene sequence similarity levels (approx. 95.5-96\%) and the low bootstrap values (Fig. 3) suggest that none of these relationships is particularly significant at present. In view of the data 
presented above, we propose to create a new genus, Allorhizobium, with one new species, Allorhizobium undicola, to describe the new $N$. natans isolates.

A number of discriminative features between Allorhizobium and its phylogenetic relatives, Rhizobium, Sinorhizobium, Mesorhizobium, Azorhizobium, Rhizobium galegae and Agrobacterium species can be found in Tables 3 and 4. In particular, at least 12 features can be used to discriminate between Allorhizobium undicola and its closest phylogenetic neighbour, Agrobacterium vitis: growth on adonitol, $N$-acetylglucosamine, Dmelibiose, D-raffinose, L-fucose, gluconate, butyrate, glutarate, DL-glycerate, L-tartrate, citrate and Lornithine (Table 3 ).

In recent years, polyphasic research into the genus Rhizobium has resulted in its gradual subdivision, with the proposal of Bradyrhizobium (Jordan, 1982), Sinorhizobium (Chen et al., 1988) and, more recently, Mesorhizobium (Jarvis et al., 1997). The proposal of Allorhizobium is a further step in this process. From the phylogenetic data (Fig. 3), it is evident that the taxonomic position of Rhizobium galegae and Agrobacterium vitis should be revised because these species are distinct from the phylogenetic groups containing the type strain of their genus. However, our study mainly concerned the new Neptunia isolates and therefore we refrain from making any formal proposals for these other taxa just yet. The taxonomic revision of Rhizobium galegae and Agrobacterium vitis is a complex issue, linked with the revision of the genus Agrobacterium, and can only be attempted after extensive study of the literature data and international consultation.

\section{Description of Allorhizobium gen. nov.}

Allorhizobium gen. nov. (Al.lo.rhi.zo'bi.um. Gr. adj. allos other; M.L. neut. n. Rhizobium a bacterial generic name; M.L. neut. n. Allorhizobium the other Rhizobium, to refer to the fact that it is phylogenetically separate from other rhizobia).

Aerobic, Gram-negative, non-spore-forming rods that are $0.5-0.7 \mu \mathrm{m}$ wide by $2-4 \mu \mathrm{m}$ long. Strains grow fast and form colonies of $0.5-3 \mathrm{~mm}$ diameter within $1-2 \mathrm{~d}$ on yeast mannitol mineral salts agar. Pronounced turbidity develops after $1-2 \mathrm{~d}$ in agitated broth media. Chemo-organotrophic, utilizing a wide range of carbohydrates, organic acids and amino acids as sole carbon sources for growth (Table 3). Discriminative features between Allorhizobium and other related genera and phylogenetic groups are shown in Table 4. 3-Ketolactose is not produced from lactose. Growth on carbohydrate media is usually accompanied by extracellular polysaccharide production. The organisms are typically able to invade the root hairs of some temperate-zone (Medicago sativa) and some tropical zone (Neptunia natans, Acacia senegal, Acacia seyal, Acacia tortilis subsp. raddiana, Lotus arabicus, Faidherbia albida) leguminous plants (family Leguminosae) and induce the production of root nodules, wherein the bacteria occur as intracellular symbionts. All strains exhibit host specificity. No strain was found to nodulate Sesbania rostrata, Sesbania pubescens, Sesbania grandiflora, Vigna unguiculata or Macroptilium atropurpureum. The $\mathrm{G}+\mathrm{C}$ content of the DNA is $60.1 \mathrm{~mol} \%$ (by $T_{\mathrm{m}}$ ). The type species is Allorhizobium undicola. At the molecular level the genus can be recognized by SDS-PAGE whole-cell protein analysis, ITS PCR-RFLP and 16S rRNA gene sequencing.

\section{Description of Allorhizobium undicola sp. nov.}

Allorhizobium undicola (un.di'co.la. L. n. unda water; L. suff. cola dweller; L. n. undicola water-dweller, referring to the isolation of these strains from nodules of the aquatic plant Neptunia natans).

Strains have all the characteristics of the genus Allorhizobium. They grow fast and form colonies of 0.5-3 mm diameter within 1-2 $\mathrm{d}$ on YMA. Colonies are round, creamy, convex to drop-like, beigecoloured; margin and surface have a smooth aspect. Aerobic, Gram-negative, non-spore-forming rods that are $0.5-0.7 \mu \mathrm{m}$ wide by $2-4 \mu \mathrm{m}$ long. Motile in liquid medium. A wide range of carbohydrates, organic acids and amino acids are utilized as sole carbon sources for growth (Table 3). Discriminating features from related species are given in Table 3. Strains are 3-ketolactosenegative. Strains can induce nitrogen-fixing nodules on their original host $N$. natans and can also nodulate Medicago sativa, Acacia senegal, Acacia seyal, Acacia tortilis subsp. raddiana, Lotus arabicus and Faidherbia albida, but nodules do not always fix nitrogen. No strain was found to nodulate Sesbania rostrata, Sesbania pubescens, Sesbania grandiflora, Vigna unguiculata or Macroptilium atropurpureum.

They can be differentiated by SDS-PAGE of their total cellular proteins, and at the molecular level by PCRRFLP profiles of the ITS and the sequence of their $16 \mathrm{~S}$ rRNA gene.

The well-studied strain ORS 992 ${ }^{\mathrm{T}}$ (=LMG 11875), isolated from $N$. natans in Senegal, is designated as the type strain and its features are given in Tables 2 and 3 . The $\mathrm{G}+\mathrm{C}$ content of ORS $992^{\mathrm{T}}$ is $60 \cdot 1 \mathrm{~mol} \%$. All Allorhizobium undicola strains have been deposited in the Culture Collection of the Laboratorium voor Microbiologie, University of Gent, in the Culture Collection of the Laboratory of Soil Microbiology, ORSTOM, Dakar, Senegal, and in the Culture Collection of LSTM, CIRAD-ORSTOM, Baillarguet, France.

\section{ACKNOWLEDGEMENTS}

We thank F. Dazzo, E. James and J. Sprent for helpful discussions. We thank D. Monget and bioMérieux, Montalieu-Vercieu, France, for kindly supplying API galleries. We thank B. Pot for helpful discussion and software assistance and J. Bakhoum, P. Tendeng, D. Badji, O. Camara and T. Badji for technical assistance. This work was supported by the Commission of the European Com- 
munities (STD3 programme, contract TS2 0169-F; BRIDGE programme, contracts BIOT-CT91-0263 and BIOT-CT91-0294; by French and Belgian Embassies through Programme d'Actions Intégrées franco-belge Tournesol 94085). M.G. is indebted to the Fund for Scientific Research - Flanders (Belgium), for research and personnel grants. A.W. is indebted to the Fund for Scientific Research-Flanders (Belgium) for a position as postdoctoral research fellow.

\section{REFERENCES}

Allen, O. N. \& Allen, E. K. (1981). The Leguminosae. A Source Book of Characteristics, Uses, and Nodulation. Madison: University of Wisconsin Press.

Amarger, N., Macheret, V. \& Laguerre, G. (1997). Rhizobium gallicum sp. nov. and Rhizobium giardinii sp. nov., from Phaseolus vulgaris nodules. Int J Syst Bacteriol 47, 996-1006.

Bernaerts, M. J. \& De Ley, J. (1963). A biochemical test for crown gall bacteria. Nature 197, 406407.

Boucher, C., Van Gijsegem, F., Barberis, P., Arlat, A. M. \& Zischek, C. (1987). Pseudomonas solanacearum genes controlling both pathogenicity on tomato and hypersensitivity on tobacco are clustered. J Bacteriol 169, 5626-5632.

Bouzar, H. (1994). Request for a judicial opinion concerning the type species of Agrobacterium. Int J Syst Bacteriol 44, 373-374.

Bouzar, H., Jones, J. B. \& Bishop, A. L. (1995). Simple cultural tests for identification of Agrobacterium biovars. In Methods in Molecular Biology, vol. 44, Agrobacterium Protocols, pp. 9-13. Edited by K. M. A. Gartland \& M. R. Davey. Totowa, NJ: Humana.

Chen, W. X., Yan, G. H. \& Li, J. L. (1988). Numerical taxonomic study of fast-growing soybean rhizobia and a proposal that Rhizobium fredii be assigned to Sinorhizobium gen. nov. Int $J$ Syst Bacteriol 38, 392-397.

Chen, W. X., Li, G. S., Qi, Y. L., Wang, E. T., Yuan, H. L. \& Li, J. L. (1991). Rhi-obium huakuii sp. nov. isolated from the root nodules of 4stragalus sinicus. Int J Syst Bacteriol 41, 275-280.

Chen, W., Wang, E., Wang, S., Li, Y., Chen, X. \& Li, Y. (1995). Characteristics of Rhizobium tianshanense sp. nov., a moderately and slowly growing root nodule bacterium isolated from an arid saline environment in Xinjiang, People's Republic of China. Int I Syst Bacteriol 45, 153-159.

De Ley, J. (1970). Reexamination of the association between melting point, buoyant density, and chemical base composition of deoxyribonucleic acid. $J$ Bacteriol 101, 737-754.

De Ley, J. (1991). The Proteobacteria: ribosomal RNA cistron similarities and bacterial taxonomy. In The Prokaryotes, 2nd edn, pp. 2109-2140. Edited by A. Balows, H. G. Trüper, M. Dworkin. W. Harder \& K. H. Schleifer. New York: Springer.

Devereux, J., Haeberli, P. \& Smithies, O. (1984). A comprehensive set of sequence analysis programs for the VAX. Nucleic Acids Res 12, 387-395.

Dreyfus, B. L., Alazard, D. \& Dommergues, Y. R. (1984). Stem nodulating rhizobia. In Current Perspectives in Microbial Ecology, pp. 161-169. Edited by M. J. Klug \& C. A. Reddy. Washington, DC: American Society for Microbiology.

Dreyfus, B., Garcia, J. L. \& Gillis, M. (1988). Characterization of Azorhizobium caulinodans gen. nov., sp. nov., a stem-nodulating nitrogen-fixing bacterium isolated from Sesbania rostrata. Int $J$ Syst Bacteriol 38, 89-98.

Eardly, B. D., Materon, L. A., Smith, N. H., Johnson, D. A., Rumbaugh, M. D. \& Selander, R. K. (1990). Genetic structure of natural populations of the nitrogen-fixing bacterium Rhizobium meliloti. Appl Environ Microbiol 56, 187-194.

Felsenstein, J. (1982). Numerical methods for inferring evolutionary trees. $Q$ Rev Biol 57, 379-404.

James, E. K., Sprent, J., Sutherland, J., McInroy, S. \& Minchin, F. (1992). The structure of nitrogen fixing root nodules on the aquatic mimosoid legume Neptunia plena. Ann Bot 69, 173-180.

Jarvis, B. D. W., Gillis, M. \& De Ley, J. (1986). Intra- and intergeneric similarities between the ribosomal ribonucleic acid cistrons of Rhizobium and Bradyrhizobium species and some related bacteria. Int J Syst Bacteriol 36, 129-138.

Jarvis, B. D. W., Van Berkum, P., Chen, W. X., Nour, S. M., Fernandez, M. P., Cleyet-Marel, J.-C. \& Gillis, M. (1997). Transfer of Rhizobium loti, Rhizobium huakuii, Rhizobium ciceri, Rhizobium mediterraneum, and Rhizobium tianshanense to Mesorhizobium gen. nov. Int J Syst Bacteriol 47, 895-898.

Jordan, D. C. (1982). Transfer of Rhizobium japonicum Buchanan 1980 to Bradyrhizobium gen. nov., a genus of slow-growing, root nodule bacteria from leguminous plants. Int $J$ Syst Bacteriol 32, 136-139.

Kersters, K. \& De Ley, J. (1984). Genus III. Agrobacterium Conn 1942. In Bergey's Manual of Systematic Bacteriology, vol. 1, pp. 244-254. Edited by N. R. Krieg \& J. G. Holt. Baltimore: Williams \& Wilkins.

Kersters, K., De Ley, J., Sneath, P. H. A. \& Sackin, M. (1973). Numerical taxonomic analysis of Agrobacterium. J Gen Microbiol 78, 227-239.

de Lajudie, P., Willems, A., Pot, B. \& 7 others (1994). Polyphasic taxonomy of rhizobia: emendation of the genus Sinorhizobium and description of Sinorhizobium meliloti comb. nov., Sinorhizobium saheli sp. nov., and Sinorhizobium teranga sp. nov. Int $J$ Syst Bacteriol 44, 715-733.

de Lajudie, P., Willems, A., Nick, G. \& 9 other authors (1998). Characterization of tropical tree rhizobia and description of Mesorhizobium plurifarium sp. nov. Int $J$ Syst Bacteriol 48, 369-382.

Laemmli, U. K. (1970). Cleavage of structural proteins during assembly of the head of bacteriophage T4. Nature 227, 680-685.

Lawson, P. A., Gharbia, S. E., Shah, H. N. \& Clark, D. R. (1989). Recognition of Fusobacterium nucleatum sub-groups Fn-1, Fn2 and $\mathrm{Fn}-3$ by ribosomal RNA gene restriction patterns. FEMS Microbiol Lett 65, 41-46.

Marmur, J. (1961). A procedure for the isolation of deoxyribonucleic acid from microorganisms. J Mol Biol 3, 208-218.

Marmur, J. \& Doty, P. (1962). Determination of the base composition of deoxyribonucleic acid from its thermal denaturation temperature. $J$ Mol Biol 5, 109-118.

Martínez-Romero, E., Segovia, L., Mercante, F. M., Franco, A. A., Graham, P. \& Pardo, M. A. (1991). Rhizobium tropici, a novel species nodulating Phaseolus vulgaris L. beans and Leucaena sp. trees. Int J Syst Bacteriol 41, 417-426.

Napoli, C., Dazzo, F. \& Hubbell, D. (1975). Ultrastructure of infection and common antigen relationships in Aeschynomene. In Proceedings of the 5th Australian Legume Nodulation Conference, Brisbane, Australia, pp. 35-37. Edited by J. Vincent. University of New South Wales.

Ndoye, I., de Billy, F., Vasse, J., Dreyfus, B. \& Truchet, G. (1994). Root nodulation of Sesbania rostrata. $J$ Bacteriol 176 , 1060-1068.

Normand, P., Ponsonnet, C., Nesme, X., Neyra, M. \& Simonet, P. (1996). ITS analysis of prokaryotes. In Molecular Microbial Ecology Manual, pp. 1-12. Edited by A. D. L. Akkermans, J. 
D. van Elsas \& F. J. De Bruijn. Dordrecht, The Netherlands: Kluwer.

Nour, S. M., Cleyet-Marel, J.-C., Normand, P. \& Fernandez, M. P. (1995). Genomic heterogeneity of strains nodulating chickpeas (Cicer arietinum L.) and description of Rhizobium mediterraneum, sp. nov. Int J Syst Bacteriol 45, 640-648.

Nour, S. M., Fernandez, M. P., Normand, P. \& Cleyet-Marel, J.-C. (1994). Rhizobium ciceri sp. nov., consisting of strains that nodulate chickpeas (Cicer arietinum L.). Int J Syst Bacteriol 44, 511-522.

Pot, B., Gillis, M., Hoste, B., Van De Velde, A., Bekaert, F., Kersters, K. \& De Ley, J. (1989). Intra- and intergeneric relationships of the genus Oceanospirillum. Int J Syst Bacteriol 39, 23-34.

Pot, B., Vandamme, P. \& Kersters, K. (1994). Analysis of electrophoretic whole organism protein fingerprints. In Modern Microbial Methods: Chemical Methods in Prokaryotic Systematics, pp. 493-521. Edited by M. Goodfellow \& A. G. O'Donnell. Chichester: Wiley.

Rinaudo, G., Orenga, S., Fernandez, M. P., Meugnier, H. \& Bardin, R. (1991). DNA homologies among members of the genus Azorhizobium and other stem- and root-nodulating bacteria isolated from the tropical legume Sesbania rostrata. Int J Syst Bacteriol 41, 114-120.

Rome, S., Fernandez, M. P., Brunel, B., Normand, P. \& CleyetMarel, J. C. (1996). Sinorhizobium medicae sp. nov., isolated from annual Medicago spp. Int $J$ Syst Bacteriol 46, 972-980.

Sawada, H., leki, H., Oyaizu, H. \& Matsumoto, S. (1993). Proposal for rejection of Agrobacterium tumefaciens and revised descriptions for the genus Agrobacterium and for Agrobacterium radiobacter and Agrobacterium rhizogenes. Int J Syst Bacteriol 43, 694-702.

Schaede, R. (1940). Die knöllchen der adventiven Wasserwurzeln von Neptunia oleracea und ihre Bacteriensymbiose. Planta 31, $1-21$.

Segovia, L., Young, J.P.W. \& Martínez-Romero, E. (1993). Reclassification of American Rhizobium leguminosarum biovar phaseoli type I strains as Rhizobium etli sp. nov. Int J Syst Bacteriol 43, 374-377.
Stackebrandt, E. \& Goebel, B. M. (1994). A place for DNA-DNA reassociation and $16 \mathrm{~S}$ rRNA sequence analysis in the present species definition in bacteriology. Int $J$ Syst Bacteriol 44, 846-849.

Stackebrandt, E., Murray, R. G. E. \& Trüper, H. G. (1988). Proteobacteria classis nov., a name for the phylogenetic taxon that includes the "purple bacteria and their relatives". Int $J$ Syst Bacteriol 38, 321-325.

Subba Rao, N. S., Mateos, P. F., Baker, D., Pankratz, H. S., Palma, J., Dazzo, F. B. \& Sprent, J. I. (1995). The unique root-nodule symbiosis between Rhizobium and the aquatic legume, Neptunia natans (L.f.) Druce. Planta 196, 311-320.

Trinick, M. J. (1980). Relationships amongst the fast-growing rhizobia of Lablab purpureus, Leucaena leucocephala, Mimosa spp., Acacia farnesiana and Sesbania grandiflora and their affinities with other rhizobial groups. $J$ Appl Bacteriol 49, 39-53.

Trüper, H. G. \& de' Clari, L. (1997). Taxonomic note: necessary correction of specific epithets formed as substantives (nouns) "in apposition". Int J Syst Bacteriol 47, 908-909.

Vauterin, L. \& Vauterin, P. (1992). Computer-aided objective comparison of electrophoresis patterns for grouping and identification of microorganisms. Eur Microbiol 1, 37-41.

Vincent, J. M. (1970). A manual for the practical study of rootnodule bacteria. In International Biological Programme Handbook no. 15, pp. 73-97. Oxford: Blackwell.

Willems, A. \& Collins, M. D. (1993). Phylogenetic analysis of rhizobia and agrobacteria based on $16 \mathrm{~S}$ ribosomal DNA sequences. Int J Syst Bacteriol 43, 305-313.

Yanagi, M. \& Yamasato, K. (1993). Phylogenetic analysis of the family Rhizobiaceae and related bacteria by sequencing of $16 \mathrm{~S}$ rRNA gene using PCR and DNA sequencer. FEMS Microbiol Lett 107, 115-120.

Young, J. P. W. (1991). Phylogenetic classification of nitrogenfixing organisms. In Biological Nitrogen Fixation, pp. 43-86. Edited by G. Stacey, R. H. Burris \& H. J. Evans. New York: Chapman \& Hall.

Young, J. P. W. \& Haukka, K. E. (1996). Diversity and phylogeny of rhizobia. New Phytol 133, 87-94. 